\title{
Contamination and Adulteration in Arecanut (Areca Catechu L.) And Its Chewing Foms: The Less Focused Subject by Health Researchers
}

\author{
Dr. Sarpangala Keshava Bhat ${ }^{1}$, Dr. Devasya Ashwin ${ }^{2}$, Dr. Mythri Sarpangala ${ }^{3}$ \\ ${ }^{I}$ Executive officer Arecanut Research and Development Foundation ${ }^{\circledR}$, Varanashi Towers, Mission St., \\ Mangaluru: 575001 \\ ${ }^{2}$ Senior Lecturer, Dept of Pedodontics and Preventive Dentistry, Kannur dental college, Anjarakandy, Kannur, \\ kerala state, India \\ ${ }^{3}$ Senior Lecturer, Dept of Periodontology, Kannur dental college, Anjarakandy, Kannur, kerala state, India
}

\begin{abstract}
Arecanut, Areca catechu L., along with certain other ingredients is the oldest common masticatory in most of the countries. It is generally chewed as it is believed to have lots of medicinal properties. Several Scientific data are now available to support this. On the other hand, lots of reports are also there on the adverse effects of chewing such products on human health. Most of the data collected on the adverse effects of chewing arecanut were from the people who chewed betel quid or pan masala. Both these chewing products usually contain several other ingredients, generally undisclosed, along with arecanut. While reviewing the research papers it was found that several samples of arecanut and its chewing product like pan masala available in the market were either contaminated with cancer causing fungi or adulterated with dangerous chemicals, pesticides and heavy metals which are known to cause several health problems on human beings. In spite of such scientific reports, it is most unfortunate that most of the researchers who highlighted the ill effects of chewing arecanut products simply blamed arecanut for all the adverse effects without properly analyzing the chewing products for the actual chemical contents in them. An attempt has been made in this paper to review the works carried out on the contamination and adulteration of arecanut samples available in the market and urged the health researchers to look into such aspect also before blaming arecanut for all the consequences.
\end{abstract}

Keywords: areca catechu, aflatoxin, contamination

\section{Introduction}

Arecanut, the fruit of the oriental palm, Areca catechu Linn., is the oldest common masticatory used along with other ingredients among humans all over the world ${ }^{[1]}$. Areca palm is distributed mainly in South and South East Asia, especially in India, China, Bangladesh, Indonesia, Myanmar, Thailand, Malaysia, Vietnam, the Philippines, etc. ${ }^{[2]}$. The endosperm of areca fruit, which is commonly called as arecanut (misnamed as betel nut in some parts of the world as it is usually chewed along with the leaves of Piper betle vine) or supari, is generally marketed after processing. In India, two types of processed arecanut varieties are commonly available, one called 'red supari' and another 'white supari' ${ }^{[3]}$. The former type is obtained by boiling and drying dehusked unripe arecanuts at different stages of maturity, whereas the latter type is obtained by drying ripe arecanuts and dehusking them later on. India ranks first in both area and production of this commodity ${ }^{44]}$. In India, the antiquity of chewing arecanut goes back to $650 \mathrm{BC}$ as mentioned in the work of Magha in 'Sisupala Vadha, ${ }^{[5]}$. In other countries such as Vietnam, the antiquity of arecanut chewing goes back to the Bronze age ${ }^{[6]}$.

Arecanut, along with several other ingredients, is being chewed by many in several countries as it is believed to have numerous medicinal values ${ }^{[7,8]}$. It has an important place in the ancient Indian system of medicine such as Ayurveda, Unani and Homeopathy ${ }^{[9,10]}$ and in clinical practices in certain other countries such as Philippines, China and other south and southeast Asian countries ${ }^{[11-13]}$. The World Health Organization ${ }^{[14]}$ has listed out as many as 25 beneficial effects of A. catechu. It was also reported that all the alkaloids present in arecanut possess drug-like properties ${ }^{[15]}$. Most of the folklore medicinal properties of arecanut are now validated and authenticated with proper scientific data. It has antioxidant, anti-inflammatory and analgesic ${ }^{[16]}$, anti-diabetic $^{[17]}$, hypolipidemic ${ }^{[18]}$, antibacterial ${ }^{[19]}$, anti-fungal ${ }^{[20]}$, anti-malerial ${ }^{21]}$, anti-viral ${ }^{[22]}$, anti-HIV and $\operatorname{AIDS}^{[23,24]}$, anti-aging by reducing wrinkles formation in skin ${ }^{[25]}$, learning and memory improvement ${ }^{[26]}$, wound healing ${ }^{[27]}$, anti-ulcer ${ }^{[28]}$, anti-migraine ${ }^{[29]}$, antihypertensive ${ }^{[30]}$, antidepressant ${ }^{[31]}$, anti-allergic ${ }^{[32]}$, anthelmintic $^{[33]}$, aphrodisiac ${ }^{[34]}$, hepatoprotective ${ }^{[35]}$, cytoprotective $^{[36]}$, and anti-cancer ${ }^{[37]}$, etc.

The chemical constituents of arecanut (both green and ripe) include 17-26\% polysaccharides, 11-30\% polyphenols, $8-15 \%$ fibres, $8-15 \%$ fats, $6-9 \%$ proteins, $1-2.5 \%$ ash and $0.11-0.24 \%$ alkaloids $^{[38]}$ such as arecoline, arecaidine, guvacine, guvacoline, isoguvacoline, arecolidine and homoarecoline ${ }^{[15]}$. Arecanut also contains Vitamin B6 $(286.9 \mathrm{mg} \%)$ and Vitamin C $(416.2 \mathrm{mg} \%)^{[39]}$. The Fatty acid compositions of arecanut are: 
lauric acid (19.5\%), myristic acid (46.2\%), palmitic acid (12.7\%), oleic acid (6.2\%), linoleic acid (5.4\%), hexadecenoic acid (7.2\%) and minorproportions of stearic acid, decanoic acid and monoethylenic acids ${ }^{[40]}$. Polyphenols were reported to decrease whereas polysaccharides, alkaloids, fats and fibres increase with maturity of the nut ${ }^{[41]}$. All the major chemical constituents of arecanut, including arecoline decrease significantly when the nuts are dried and stored with husk as whole nuts and also while roasting, soaking and boiling $[42,43]$.

\section{Chewing forms of arecanut}

Arecanut or betel nut is generally chewed along with other ingredients in four different forms: one wet type called 'betel quid' and three other types are dry forms called 'pan masala', 'gutka' and 'sweet supari' [44]. The constituents of betel quid differ in various countries. It generally contains ingredients such as the leaf of $P$. betle, slaked lime, catechu (Acacia catechu), certain spices, artificial sweeteners such as saccharin and essences in different proportions ${ }^{[45]}$. In countries such as Taiwan, Papua New Guinea, etc., instead of the leaf of $P$. betle its inflorescence, fruits or stem are used in making the quid ${ }^{[46,47]}$. The betel quid is either chewed as such or chewed with the addition of a piece of tobacco (Nicotiana tabacum) as per individual preference ${ }^{[4]}$.

Pan masala is a packaged form of chewing product containing arecanut, lime, catechu, condiments and certain flavoring agents and artificial sweeteners. Generally pan masala does not contain tobacco. When tobacco is mixed with pan masala it is called as gutka, zarda or khaini. Sweet supari is another form of packaged arecanut which is processed and flavored ${ }^{[44]}$. All the dry forms of these chewing products are manufactured industrially and available in market in small (four to five gram) sachets in different brand names. Though the chewing habit varies among people in different regions, the betel quid or its commercial preparations are kept chewing inside the mouth for about $15 \mathrm{~min}$ to an hour and repeated five to six times a day. In most of the cases the chewed substance is spit out and rarely consumed ${ }^{[44]}$.

\section{Contaminations and adulterations in arecanut}

As the arecanut products are available in the market in several types of ready to chew forms, there is every possibility that such forms are adulterated with cheaper materials and preservatives irrespective of their health hazards. Reports are already available that most of the arecanuts available in the market were of substandard and contaminated with cancer causing fungus ${ }^{[48-50]}$ and also adulterated with several hazardous phytochemicals, toxic metals and even pesticides ${ }^{[51]}$. Chewing of such poor quality and adulterated arecanuts would definitely pose severe health problems on human beings in long time ${ }^{[48,52]}$. An attempt has been made in this paper to review the extent of contaminations and adulterations of betel quid and pan masala available in the market and how serious the health researchers are on such aspects.

\section{Contamination of arecanut with 'aflatoxin' producing fungus}

Aflatoxins are fungal toxins inducing acute toxicity, carcinogenicity and several other adverse effects on human health ${ }^{[52]}$. The fungi responsible for the production of aflatoxins are mainly Aspergillus flavus and $A$. parasiticus. Four types of aflatoxins, B1, B2, G1 and G2 commonly infest food items. Among them aflatoxin B1 is considered to be the most potent one accounting for nearly $70 \%$ of the total aflatoxin content in food. Children are affected most by aflatoxin ingestion leading to stunted growth, liver damage and even liver cancer. Adults are also at risk but have a higher tolerance limit ${ }^{52]}$. It was reported that arecanuts, with high moisture content and if not processed and dried properly ${ }^{[53]}$ or harvested prematurely and allowed to dry in heaps ${ }^{[49]}$ are invariably attacked by such fungi. The central core portion (pith) of arecanut, which is soft and sweet is mostly preferred as the site of infection and the infection by these fungi gives a dark patchy appearance to the inside core $^{[49]}$. Contamination of arecanut with such cancer causing fungi is reported in several countries. Continuous consumption of such aflatoxin contaminated food, even if they are in small doses can lead to many human health problems ${ }^{[54]}$.

Infestation of A. flavus was commonly reported in Indian arecanuts. It was found in stored and marketed indigenous ${ }^{[50,53,55,56]}$ as well as imported arecanuts to this country ${ }^{[57]}$. This fungus was also reported to be the predominant one among several other fungal species identified in arecanut samples found in the markets of Lucknow and Gulbarga cities of India ${ }^{[48,50]}$. Seven species of Aspergillus, including A. flavus and A. niger were isolated from the arecanut samples in Lucknow market and the concentration of aflatoxin B1 was found to be $51.09 \mu \mathrm{gg} / \mathrm{kg}$, much higher than the tolerance limit fixed by WHO. A. flavus and A. niger were also isolated from the arecanut samples from Gulbarga. The concentration of aflatoxin in such arecanut samples of Gulbarga were not given in the report. In another study conducted on the infestation of aflatoxin in arecanut in India it was noticed that out of 32 arecanut samples, $12(37.5 \%)$ were found to be contaminated with aflatoxins with an average aflatoxin B1 content as high as $94 \mu \mathrm{g} / \mathrm{kg}$ (range: 18-208) and average total aflatoxin $(\mathrm{B} 1+\mathrm{B} 2+\mathrm{G} 1+\mathrm{G} 2)$ content of $137 \mu \mathrm{g} / \mathrm{kg}$ (range 18-293) ${ }^{[58]}$. 
Aflatoxin contamination in arecanut was also noticed in several other countries. Both aflatoxin B1 and G1 were recovered from the arecanut samples in Malaysia ${ }^{[59]}$. In a study on the prevalence of aflatoxin B1 (the most potent among the aflatoxins group) in 278 arecanut samples imported to Pakisthan from other countries during 2010-2011 (India-21 samples, Indonesia-51. Sri lanka-34 and Thailand-172 samples), all samples $(100.0 \%)$ of arecanuts of Indian origin showed aflatoxin B1 contamination ranging from 11.7-267.0 $\mu \mathrm{g} / \mathrm{kg}$ with a mean of $92.5 \mu \mathrm{g} / \mathrm{kg}{ }^{[60]}$. The figures for Indonesia, Sri Lanka and Thailand were $80.4 \%, 73.5 \%$ and $30.2 \%$ with aflatoxin B1 ranging from 3.3 - 39.2 (mean 11.6), 6.5 - 103.4 (mean 35.0) and $3.3-77.0 \mu \mathrm{g} / \mathrm{kg}$ (mean $6.65 \mu \mathrm{g} / \mathrm{kg}$ ), respectively. A rapid cross-sectional study conducted at Bangladesh on the extent of aflatoxin contamination in several human food items and poultry feed revealed the presence of aflatoxin at 30.6ng/g level in the samples of their arecanuts ${ }^{[61]}$. In Nepal, it was reported that as many as $25 \%$ of arecanut samples were found to be contaminated with aflatoxin $\mathrm{B} 1$ or $\mathrm{B} 2^{[54]}$. They further presumed that intake of aflatoxin contaminated food might be an important unrecognized risk factor to public health which could have long-term health implications if not attended properly.

In South Africa it was noticed that nearly 40 to $60 \%$ of dried arecanut samples (sliced or whole) imported were found to be contaminated with A. flavus, and the concentration of aflatoxin B1 in such arecanuts was found to be in excess of the commonly accepted food limit ${ }^{[62,63]}$. Based on the arecanut consumption data it was also calculated that chewers of un-boiled dried arecanuts in South Africa may consume a total aflatoxin $(\mathrm{B} 1+\mathrm{B} 2+\mathrm{G} 1+\mathrm{G} 2)$ content of 3.6-1080 ng per $24 \mathrm{~h}^{[62]}$. They also presumed that in countries such as India and Taiwan where the people mostly chew similar type of arecanut, the concentration of aflatoxins consumed may even go up and potentially contribute to the reported carcinogenic effects of different chewing products of arecanut on human oral tissue. In spite of such widespread presence of aflatoxin in arecanut, the health researchers did not take care of this aspect seriously, but simply blamed arecanut for all the ill effects.

\section{Adulteration in Pan masala}

Though the label in pan masala sachets gives an impression that they contain arecanut along with certain other condiments and flavouring agents, most of the brands neither revealed all the contents nor mentioned the actual quantity of each ingredient in them. There was no proper quality control on these products either in several countries. In such circumstances, there is every possibility that substandard / spurious / adulterated materials which are dangerous to human being might have been incorporated for some reason or the other in different brands. The chemical composition of the food material is primarily responsible for its biochemical activity and related health implication. Presence of polycyclic aromatic hydrocarbons (PAH) and certain toxic metals such as lead, cadmium and nickel were already reported in all the five common pan masala brands tested in Ahmadabad, India ${ }^{[64]}$. Though the actual levels of these compounds in the products tested were not given in this report, in another laboratory study on the chemical composition of several common brands of pan masala, it was found that most of them were adulterated with PAH, certain insecticides such as DDT and BHC isomers, in addition to toxic metals such as copper, zinc and magnesium (all these are known to possess carcinogenic, tumorigenic, teratogenic and mutagenic potentials), in higher concentrations than permissible limits ${ }^{[51]}$. High concentrations of toxic metals such as lead, arsenic, cadmium and copper, much above the permissible limits prescribed by the WHO, were also detected in several Indian brands of tobacco blended pan masala ${ }^{[65]}$. Several dangerous volatile aldehydes, such as formaldehyde, acrolein, crotonaldehyde, propionaldehyde and isobutyraldehyde have also been detected in the studies conducted on the chemical analysis of pan masala in the Cancer Research Institute of Tata Memorial Centre, Mumbai, India ${ }^{\text {[64] }}$.

The adulteration in pan masala was so common that certain brands of these products which claimed that they were 'tobacco free' contained up to $13.28 \mathrm{~g}$ of nicotine (a known carcinogen) per $100 \mathrm{~g}$ of the content (The Tribune, Feb 21, 2011). It was also reported that certain other brands of pan masala contained 'menthol', an organic compound mainly used against colds and throat irritation as topical application, in more concentration than the acceptable limit for food stuffs fixed by the Food Adulteration Act of India. Though this act fixed the maximum level of menthol in pan masala at $0.1 \%(1.0 \mathrm{mg} / \mathrm{g})$, it was noticed that as many as $75 \%$ of samples of branded pan masala contained 1.1-6.5mg of menthol per gram of the product and in non branded pan masala up to $92 \%$ of the samples contained $1.1-6.5 \mathrm{mg}$ of menthol per gram of the product ${ }^{[66]}$. There were reports to show that chronic intake of menthol was injurious to human health ${ }^{[67]}$. Most of the pan masala and pan flavorings found in Indian market were reported to contain artificial sweetener, saccharin, a known urinary bladder carcinogen, in several folds higher than the maximum levels permitted by the Prevention of Food Adulteration (PFA) Act of India ${ }^{[68]}$. Hence, it is highly necessary for the concerned Government Departments to make regular and surprise chemical analysis of different brands of pan masala available in the market and curb such illegal activities for the benefit of mankind. The researchers should also consider all these factors before labeling only one constituent of pan masala as carcinogenic or dangerous. In spite of such dangerous reports on the widespread contamination and adulteration of arecanut and its chewing products, it is strange that most of the research papers which reported the harmful effects of chewing arecanut products did not either analyzed the 
actual contents of the chewing products they dealt with, or took note of the harmful effects of other ingredients or the contaminations and adulterations found on such ingredients, but simply tagged arecanut for all the adverse consequences developed by chewing these products ${ }^{[69-83]}$. Ample number of review articles ${ }^{[45,84-92]}$ have also emerged blaming arecanut, but none took care to pinpoint or discuss the contaminations or adulterations found on such chewing products in their articles.

\section{Conclusion}

These observations clearly shows that ample quantity of arecanuts in the market are contaminated with the cancer causing fungus, Aspergillus flavus which produce the toxic chemical 'aflatoxin'. Nearly $37.5 \%$ of arecanut samples in India were found infested with such fungus. Several brands of pan masala were also reported to be adulterated with toxic chemicals like polycyclic aromatic hydrocarbons and dangerous insecticides such as DDT and BHC isomers in addition to toxic metals such as copper, zinc and magnesium. Certain 'tobacco free' pan masala brands were even contained nicotine in very high concentration and certain others contained menthol and saccharin in much higher concentration than the maximum levels permitted by the Prevention of Food Adulteration (PFA) Act of India. Most of the health researchers did not analyze the chewing products of arecanuts they studied for such contaminations and adulterations, but simply blamed arecanut for all the ill effects. Hence, there is an urgent need to evaluate and detect the actual harmful substance responsible for the ill effects of the arecanut chewing products commonly available in the market before pin pointing a particular substance for the outcome. If found necessary, strict action may be taken on the manufacture and sale of such products for the benefit of both areca farmers and chewers of such products.

\section{References}

[1]. Arjungi KN. Areca nut: A review. Arzneimittelforschung 1976; 26: 951-6.

[2]. Balasimha D, Rajagopal V. Eds.: Balasimha D, Rajagopal V. In: Introduction. Arecanut. India. Kasaragod: Central Plantation Crops Research Institute; 2004.p.1-6.

[3]. Selvan MT, Sivaraman K, Manojkumar K. Eds.: Balasimha D, Rajagopal V. In: Economics, marketing and development. Arecanut. India. Kasaragod: Central Plantation Crops Research Institute;2004.p. 259-301.

[4]. Cheriyan H, Manojkumar K. Arecanut production scenario in India. Indian J Arecanut, Spices and Med plants 2014;16: 3-11.

[5]. Rao MM. Eds.: Bavappa, KVA Nair, Kumar TP. In: Introducnion. The Arecanut Palm. India. Kasaragod: Central Plantation Crops Research Institute; 1982.p1-9.

[6]. Oxenham MF, Locher C, Cuong NL, Thuy NK. Identification of Areca catechu (betelnut) residues on the dentition of Bronze age inhabitants of Nui Np, Northern Vietnam. Journal of Archaeological Science 2002; 29: 1-7.

[7]. Aman, Aman. Medicinal secrets of your food. Areca nut. Mysore: The Wesley Press; 1969.p700-2.

[8]. Jaiswal P, Kumar P, Singh VK, Singh DK. Areca catecu L:A valuable herbal medicine against different health problems. Res J Med Plant 2011;5:145-52.

[9]. Badanaje SB. Arecanut - Medicinal and alternative uses. India: Mangalore:Arecanut Research and Development Foundation®; 2008.p104.

[10]. Krishnamurthy KH. Medicinal uses of arecanut and coconut. India: Mangalore;Pragun Publishers. Arecanut Research and Development Foundation $® ; 2008 . p 61$.

[11]. Pardo De Tavera TH. The Medicinal Plants of the Philippines. Blakiston's Son \& Co.Philadelphia.1901;p269.

[12]. Li Shizhen. Category of fruits (III). In:,Compendium of materia Medica. Foreign Languages Press. China.p2805-10.

[13]. Rahmatullah,M., Mukti IJ, Haque AKMF, Mollik MAH, Parvin K, Jahan R et al. An ethnobotanical survey and pharmacological evaluation of medicinal plants used by the Garo tribal community living in Netrakona district, Bangladesh. Advances in Natural and Applied Sciences 2009; 3: 402-18.

[14]. WHO. Areca catechu L. In.; Medicinal Plants of Papua New Guinea.Geneva. Switzerland, $2009 ; \mathrm{p} 302$.

[15]. Peng W, Lie YJ, Zhao CB, Huang XS, Wu N, Hu MB et al. In silico assessment of drug-like properties of alkaloids from Areca catechu L nut. Trop J Pharmaceut Res 2015; 14: 635-9.

[16]. Bhandare A, Kshirsagar A, Vyawahare N, Hadambar A, Thorve S. Potential analgesic, anti-inflammatory and antioxidant activities of hydroalcoholic extract of Areca catechu L. nut. Food Chem Toxicol 2010; 12: 3412-7.

[17]. Anthikat RRN, Michael A, Vageesh S, Balamurugan R, Ignacimuthu S. The effect of Areca catechu L. extract on streptozotocin induced hyperglycemia in Wistar rats. Int J Pharma Bio Sci 2014;5: 316-321.

[18]. Park YB, Jeon SM, Byun SJ, Kim HS, Choi MS. Absorption of intestinal free cholesterol is lowered by supplementation of Areca catechu L. extract in rats. Life Sciences 2002; 70: 1849-59.

[19]. Hazarika DJ, Sood K. In vitro antibacterial activity of peptides isolated from Areca catechu Linn. Der Pharmacia Lettre 2015; 7: 17.

[20]. Anthikat RRN, Michael A, Kinsalin VA, Ignacimuthu S. Antifungal activity of Areca catechu L. Int J Pharma Clinical Sci 2014;4: $1-3$.

[21]. Jiang, JH, Jung SY, Kim YC, Shin SR, Yu ST, Park H. Antimalerial effects of Areca catechu L. Korean J Oriental Physiol Pathol 2009;23: 494-8.

[22]. Anthikat RRN, Michael A. Study on the arecanut for its antimicrobial properties. J Young Pharmacists 2009; 1: 42-5.

[23]. Kusumoto IT, Nakabayashi T, Kida H, Miyashiro M, Hattori M, Namba T et al. Screening of various plant extracts used in ayurvedic medicine for inhibitory effects on human immunodeficiency virus type 1 (HIV-1) protease. Phytotherapy Res.1995; 9: 180-4.

[24]. Vermani K, Garg S. Herbal medicines for sexually transmitted diseases and AIDS. J Ethno Pharmacol 2002; 80: 49-66.

[25]. Lee KK, Choi JD. The effects of Areca catechu L extract on anti-aging. Int J Cosmet Sci 1999;21: 285-95.

[26]. Joshi M, Gaonkar K, Mangoankar S, Satarkar S. Pharmacological investigation of Areca catechu extract for evaluation of learning, memory and behavior in rats. Int Current Pharmaceut J 2012;1; 128-32.

[27]. Azeez S, Amudhan S, Adiga S, Rao N, Udupa LA.Wound healing profile of Areca catechu extracts on different wound models in Wistar rats. Kuwait Med J 2007; 39: 48-52. 
[28]. Anthikat RRN, Michael A. Anti-ulcerogenic effects of Areca catechu L. in Sprague dawley rats. IJPSR 2011; 2: 179-84.

[29]. Bhandare A, Kshirsagar A, Vyawahare N, Sharma P, Mohite R. Evaluation of anti-migraine potential of Areca catechu to prevent nitroglycerin-induced delayed inflammation in rat meninges: possible involvement of NOS inhibition. J Ethnopharmacol 2011; 136: $267-70$.

[30]. Inokuchi J, Okabe H, Yamauchi T, Nagamatsu A, Nonaka G, Nishioka I. Antihypertensive substance in seeds of Areca catechu L. Life Sciences 1986;38:1375-82.

[31]. Khan S., Abbas G, Ahmed FS, Rahman AU, Dar A. Effect of dichloromethane fraction of Areca catechu nut on monoamines associated behaviors and tyramine pressor sensitivity in rodents. Pak J Pharm Sci 2014; 27: 303-7.

[32]. Lee JH, Chang SH, Park YS, Hes E, Lee HY, Park JW et al. In-vitro and in-vivo anti-allergic actions of Areca semen. J Pharm Pharmacol 2004; 56: 927-33.

[33]. KeshavaBhat S, Mythri S, Ashwin D. Anthelmintic property of arecanut.(Areca catechu L.) A review. Ind J Areca, Spices Med Plants 2016;18: 20-7.

[34]. Anthikat RRN, Michael A, Ignacimuthu S. Aphrodisiac effect of Areca catechu L. and Pedalium murex in rats. Journal of Men's Health (JMH) 2012; 10: 65-70.

[35]. Pithayanukul P, Nithitanakool S, Bavovada R. Hepatoprotective potential of extracts from seeds of Areca catechu and nutgalls of Quercus infectoria. Molecules 2009; 14: 4987-5000.

[36]. Sazwi NN, Nalina T, Rahim ZHA. Antioxidant and cytoprotective activities of Piper betle, Areca catechu, Uncarria gambir and betel quid with and without calcium hydroxide. BMC Complementary and Alternative Medicine 2013; 13: 351.

[37]. Kumari HL, Sirsi M, Bhargava MK. Inhibitory activity of Areca catechu on the development of mouse skin tumours induced by the chemical carcinogen 3.4, benzpyrene. J. Plantn Crops 1974; 2: 23-9.

[38]. Shivashankar S, Dhanaraj S, Mathew AG, Murthy SS, Vyasamurthy MN, Govindarajan VS. Physical and chemical characteristics of processed arecanuts. J Food Sci Tech 1969;6: 113-6.

[39]. Tirumaleshwara Bhat N. Alternate uses of Arecanut. J Plantn Crops 1990; 17: 72-80.

[40]. Pathak SP, Mathur SS. The component acids and glycerides of arecanut (Areca catechu) fat. J Sci Food Agri 1954; 5: $461-5$.

[41]. Mathew AG, Venkataramu SD, Govindarajan VS. Studies on arecanut: part 1. Changes in chemical composition and physical characteristics of nuts with maturity. Ind J Tech 1964; 2: $90-6$.

[42]. Chempakam B, Saraswathy N. Eds: K.S. Bhat KS, Nair CPR. Biochemical changes during storage of arecanut (Areca catechu L.). In: Arecanut Research and Development ,CPCRI, Kasaragod. India.1965; p163-6.

[43]. Awang MN.. Fate of betelnut chemical constituents following nut treatment prior to chewing and its reaction to oral precancerous \& cancerous lesion. Dental Journal of Malaysia 1988;10: 33-7.

[44]. Gandhi G, Kaur R Sharma S. Chewing pan masala and/or betel quid-fashionable attributes and/or cancer menaces? J Human Ecol 2005;17: 161-66.

[45]. IARC Monographs on the evaluation of carcinogenic risks to humans. In;.Betel quid and arecanut chewing. Lyon.France. 2004; 85:37-293.

[46]. Wu MT, Lee YC, Chen CJ, Yang PW, Lee CJ, Wu DC et al. Risk of betel chewing for oesophageal cancer in Taiwan. British J Cancer 2001;85: 658-60.

[47]. Kaius MO, Unger HW, Singirok D, Wangnapi RA, Hanieh S, Umbers AJ et al. Determining effects of areca (betel) nut chewing in a prospective cohort of pregnant women in Madang Province, Papua New Guinea. BMC Pregnancy and Childbirth 2015; 15: 177.

[48]. Misra A, Misra JK. Fungal flora of marketed betelnuts. Mycologia 1981; 73: 1202-3.

[49]. Mahdihassan S. Betel-nuts as contaminated with a cancer producing fungus. Ancient Science of Life 1987; 4: 244-6.

[50]. Muralimohan GU, Reddy CN. Incidence of aflatoxins and Aspergillus flavus in marketed arecanut and soapnut powder in Gulbarga city. Indian Phytopath 1995; 48: 371-3.

[51]. Nigam SK, Bhatt HV. Analysis and toxicity of plain (PMP) and blended (PMT) Indian pan masala (PM). Eurasian J Medicine 2013; 45: 21-33.

[52]. Gong YY, Watson S, Routledge MN. Aflatoxin exposure and associated human health effects, a review of epidemiological studies. Food Safety 2016;4: 14-27.

[53]. Nambiar KKN, Reddy K. Fungal infection of stored arecanuts. J Plantn Crops 1979; 7: 50-3.

[54]. Koirala P, Kumar S, Yadav BK, Premarajan KC. Occurrence of aflatoxin in some of the food and feed in Nepal. Ind J Med Sci 2005; 59: 331-6.

[55]. Misra JK, Raisuddin S. Occurrence of fungi in marketed betel nut. Ind J Plant Path1984;. 2: 83-4.

[56]. Chowdappa P, Iyer R, Gunasekaran M. Storage diseases. In: Plant Pathology Research at CPCRI.Kasargod. India 2004;p113.

[57]. Sharma HSS, Gilmore C, Sharma HB. Comparison of chemical components of healthy and spoiled arecanut. Mycological Res 1991; 95: 747-51.

[58]. Raisuddin S, Misra JK.. Aflatoxin in betel nut and its control by use of food preservatives. Food Add Contam 1991;8: 707-12.

[59]. Thuan CE, Amarasingham RD. Examination of areca nut for the presence of aflatoxins. Malaysian Agric J 1977;51:305-10.

[60]. Asghar MA, Iqbal J, Ahmed A, Khan MA, Shamsuddinm ZA. Aflatoxin B1 in betelnuts (Areca catechu L.) imported to Pakistan from different regions of South Asia. Food Additives \& Contaminants: Part B: Surveillance 2014; 3: 176-81.

[61]. Roy M, Harris J, Afreen S, Deak E, Gade L, Balajee SA et al..Aflatoxin contamination in food commodities in Bangladesh. Food Addit. Contam. Part B Surveill. 2013; 6: 17-23.

[62]. Bijl VDP, Stockenstrom S, Vismer HF, Wyk VCW. Incidence of fungi and aflatoxins in imported arecanut samples. South African J Sci 1996; 92: 154-6.

[63]. Bijl VDP, Stockenstrom S, Vismer HF, Wyk VCW. Further observations on the incidence of fungi and aflatoxins in arecanut samples. Ind J Exp Biol 1997;35: 796-8.

[64]. Bhisey RA. Genotoxicity and carcinogenicity of pan masala: a review. Proc Indian Nat Sci Acad (PINSA) 2000;B66(1):1-12.

[65]. Dhaware D, Deshpande A, Khandekar RN, Chowgule R. Determination of toxic metals in Indian smokeless tobacco products. The Scientific World Journal 2009; 9: 1140-7.

[66]. Kannan A, Das M, Khanna K.Estimation of menthol in pan masala samples by a spectrophotometric method. Food Addit Contam1997; 14: 367-71.

[67]. Baibars M, Simona E, Shaheen K, Alraiyer AH, Alraies MC. Menthol toxicity: an unusual case of coma. Case Rep Med 2012. Epub 2012 Dec 3.

[68]. Tripathi M, Khanna SK, Das M. Usage of saccharin in food products and its intake by the population of Lucknow, India. Food Addit Contam 2006; 23: 1265-75.

[69]. Mathew P, Austin RD, Varghese SS, Kumar MAD. Role of arecanut and its commercial products in oral submucous fibrosis- a review. J Advanced Med Dent Sci Res2014; 2: 192- 200. 
[70]. Chu NS. Neurological aspects of areca and betel chewing. Addiction Biol 2002; 7: 111-4.

[71]. Lin SH, Lin YF, Dhadli SC, Davids MR, Halperin ML. Hypercalcaemia and metabolic alkalosis with betelnut chewing: emphasis on its integrative pathophysiology. Nephrol Dial Transplant 2002: 17: 708-14.

[72]. Oakley E, Demaine L, Warnakulasuriya S. Arec (betel)nut chewing habit among high-school children in the Commonwealth of the Northern Mariana Islands (Micronesia). Bull WHO 2005; 83: 656-60.

[73]. Lan TY, Chang WC, Tsai YJ, Chuang YL, Lin HS, Tai TY. Arecanut chewing and mortlity in an elderly cohort study. Am J Epidemiol 2007;165: 677- 83.

[74]. Hazarey VK, Erlewad DM, Mundhe KA, Ughade SN. Oral submucous fibrosis: study of 1000 cases from central India. J Oral Path Med 2007; 36: 12-17.

[75]. Kang IM, Chou CY, Tseng YH, Huang CC, Ho WY, Shih CM, ChenW. Association between betelnut chewing and chronic kidney disease in adults. J Occup Environ Med 2007; 49: 776-9.

[76]. Chou CY, Cheng SY, Liu JH, Cheng WC, Kang IM., Tseng YH et al. Association between betel-nut chewing and chronic kidney disease in men. Public Health Nutrition 2008;12: 723-7.

[77]. Lin CF, Shiau TJ, Ko YC, Chen PH, Wang JD.Prevalence and determinants of biochemical dysfunction of the liver in Atayal Aborginal Community of Taiwan: Is betel nut chewing a risk factor? BMC Gastroenterology 2008;8: 13

[78]. Lin WY, Chiu TY, Lee LT, Lin CC, Huang CY, Huang KC. Betelnut chewing is associated with increased risk of cardiovascular disease and all-cause mortality in Taiwanese men. Am J Clin Nutr 2008; 87: 1204-11.

[79]. Lin WY, Pi-Sunyer FX, Liu CS, Li TC, Li CI, Huang CY, Lin CC. Betelnut chewing is strongly associated with general and central obesity in Chinese male middle-aged adults. Obesity (Silver Spring) 2009; 17: 1247-54 .

[80]. Tseng CH. Betelnut chewing and subclinical Ischemic heart disease in diabetic patients. Cardiol Res Pract 2011:1-5.

[81]. Tsai WC, Wu MT, Wang GJ, Lee KT, Lee CH, Lu YH et al. Chewing arecanut increases the risk of coronary artery in Taiwanese men: a case-control study. BMC Public Health 2012;12:162.

[82]. Shafique K, Zafar M, Ahmed Z, Khan NA, Mughal MA, Imtiaz F. Arecanut chewing and metabolic syndrome: evidence of a harmful relationship. Nutrition J 2013; 12: 67.

[83]. Yadav JS, Chadha P. Genotoxic studies in pan masala chewers: a high cancer risk group. Int J Hum Genet 2002;2:107-12.

[84]. Kumar S, Saiyed HN.Role of betelnut chewing in cancer: its toxicity and chemoprevention - an overview. Indian J Environ Toxicol 1999; 9: 5-11.

[85]. Nair U, Bartsch H, Nair J. Alert for an epidemic of oral cancer due to use of the betel quid substitutes gutka and pan masala: a review of agents and causative mechanisms. Mutagenesis 2004; 19: 251-62

[86]. Javed F, Al-Hezaiimi K, Warnakulasuriya S. Areca-nut chewing habit is a significant risk factor for metabolic syndrome: a systematic review. J Nutr Health Aging 2012; 16: 445-8.

[87]. Adhikari A, De M. Toxic effects of betel quid. Int J Hum Genet 2013;13: 7-14.

[88]. Chaturvedi P, Garg A, Gupta PC. A review of the systemic adverse effects of arecanut or betelnut. Indian Journal of Medical and Paediatric Oncology 2014; 35: 3-9.

[89]. Gupta PC, Ray CS. Arecanut use and cancer in India. Biomed Res J 2015;2: 140-65.

[90]. Shwetha HR, Babu CN, Ahmed S, Garg A. Effect of arecanut on oral epithelium - a review of literature. University J Dent Scie 2015;1: 38-41.

[91]. Anand R, Dhingra C, Prasad S, Menon I. Betel nut chewing and its deleterious effects on oral cavity. J Cncer Res Therapeutics2016; 10: 499- 505 .

[92]. Shah G, Chaturvedi P, Vaishampayan S. Arecanut as an emerging etiology of oral cancers. Ind J Med Paediatric Oncol 2016; 33 : 71-9. 